\title{
Adapting the Hodrick-Prescott Filter for Very Small Open Economies
}

\author{
Aaron George Grech ${ }^{1}$ \\ ${ }^{1}$ Central Bank of Malta, Valletta, Malta \& London School of Economics and Political Science, London, United \\ Kingdom \\ Correspondence: Aaron George Grech, Economics \& Research Department, Central Bank of Malta, Valletta, \\ VLT 1060, Malta. Tel: 356-2248-7920. E-mail: grechga@centralbankmalta.org
}

$\begin{array}{ll}\text { Received: June 12, } 2013 & \text { Accepted: June 26, } 2013 \quad \text { Online Published: July 26, } 2013 \\ \text { doi:10.5539/ijef.v5n8p39 } & \text { URL: http://dx.doi.org/10.5539/ijef.v5n8p39 }\end{array}$

\begin{abstract}
The Hodrick-Prescott (HP) filter is a commonly used method, particularly in potential output studies. However its suitability depends on a number of conditions. Very small open economies do not satisfy these as their macroeconomic series exhibit pronounced trends, large fluctuations and recurrent breaks. Consequently the use of the filter results in random changes in the output gap that are out of line with the concept of equilibrium. Two suggestions are put forward. The first involves defining the upper and lower bounds of a series and determining equilibrium as a weighted average of the filter applied separately on these bounds. The second involves an integration of structural features into the standard filter to allow researchers to set limits on the impact of structural/temporary shocks and allow for lengthy periods of disequilibria. This paper shows that these methods can result in a smoother output gap series for the smallest Euro Area economies.
\end{abstract}

Keywords: potential output, output gap, Hodrick-Prescott filter, detrending, business cycles, small open economies

\section{Introducation}

Macroeconomics is based on the concept of equilibrium, with the economy developing in the long term in a balanced way, with full employment of resources and a constant inflation rate (Note 1). However in the short term there can be deviations from this path and discovering the extent of these disequilibria is one of the main tasks of empirical macroeconomists (Note 2). Given that these long term variables are unobservable, they need to be estimated. There tend to be two main branches in the literature, particularly on potential output studies. On the one hand, statistical de-trending methods, such as the Hodrick-Prescott (HP) filter, attempt to extract equilibrium values using past values of a macroeconomic series (Note 3). The line of reasoning underlying these methods is essentially neo-classical as the economy's dynamics are assumed to gravitate towards equilibrium, so that past values of actual data should give a very good indication. By contrast, the other category of models is based on the idea that given that the economy can deviate from equilibrium for long periods, past observations can provide little indication, and a structural model, such as a production function in the case of potential output estimation, must be developed.

Both empirical approaches were conceived for large economies with relatively stable macroeconomic series. The structural methods, if they are not correctly specified or are based on an inaccurate assessment of factors of production, can provide a rather incorrect view of potential output. Unfortunately very small economies do not tend to have high quality data on factors of production, notably the capital stock. In many cases, due to data unavailability, estimates of total factor productivity and the natural rate of unemployment - both important determinants of potential output in structural methods - have to be estimated using statistical filters. However, while there is a tendency to apply statistical filters uniformly in cross-country studies, this ignores the fact that these filters tend to require quite specific properties which are not found in data for very small open economies. Due to their very open and very small nature, these economies tend to have macroeconomic series with pronounced trends, large fluctuations and recurrent structural breaks. The finalisation of a big export order or the carrying out of an infrastructural project, for instance, would tend to regularly affect their series, while for large countries these kinds of shocks tend to be rare occurrences. In this light, standard filtering methods should preferably be adjusted to take into account the special characteristics of very small open economies.

This paper will attempt to tackle this issue by looking at the use of the HP filter to derive quarterly output gap 
estimates for the six smallest Euro area (EA) economies, namely Cyprus, Estonia, Luxembourg, Malta, Slovenia and Slovakia (Note 4). All of these countries have a share of total EA GDP of less than 1\% (Note 5). They also are very open economies, with the ratio of exports to GDP more than two and a half times that of the largest EA economies. Over the last decade, they have also tended to grow at a much faster rate than the rest of the EA and to have much more volatile economic outcomes. These differences, expanded in more detail in the section 2 of this paper, mean that they are an excellent example of countries where the application of the standard HP filter could provide policymakers with an incorrect value for potential output. In section 3 of this paper, two suggestions are put forward to allow for a smoother quarterly output gap series for the smallest EA economies and, more broadly, for other economies would allow for long-term deviations from potential.

\section{Are the Very Small Economies Different from the Rest of the EA?}

There is no standard definition of what constitutes a small country. Kuznets (1960) uses an upper limit of 10 million people, whereas the Commonwealth opts for a threshold of 1.5 million (Note 6). However territory size or GDP are also used (see Alesina \& Spolaore (2003)). In this paper we denote by the very small economies of the EA all those countries with a GDP less than 1\% of the EA's total GDP. Of these, only Slovenia and Slovakia have a population higher than 1.5 million.

Studies of small economies find that they tend to be much more open to international trade and also very dependent on FDI flows (Note 7). This reflects the fact that the absence of a large domestic market creates clear incentives for a more open trade and investment regime. The export-to-GDP ratio of very small EA economies is, in fact, two and a half times that of the large EA countries. However this dependence on volatile or relatively uncontrollable external demand gives rise for an expanded scope of government to stabilise income (see Rodrik (1998)). The high volatility and exposure to external risk probably also contributes to smaller states having higher saving rates (Note 8). Figure 1 compares the quarter-on-quarter real GDP growth rate of the five largest EA economies and that of the six smallest. Besides displaying very little correlation up to the end of 2007, the two series differ greatly in terms of volatility and range. Quarter-on-quarter growth rates range from $+1.1 \%$ to $-2.9 \%$ for the largest economies and from $+2.4 \%$ to $-4.6 \%$ for the smallest ones. The latter also change very randomly. For instance, in $2007 \mathrm{Q} 4$ the quarter-on-quarter growth rate for the very small economies was $2.4 \%$, turning to a negative $0.4 \%$ in the first quarter of 2008 , again shifting to a significant positive in the second quarter. These differences are even more pronounced when one looks at particular economies (Note 9).

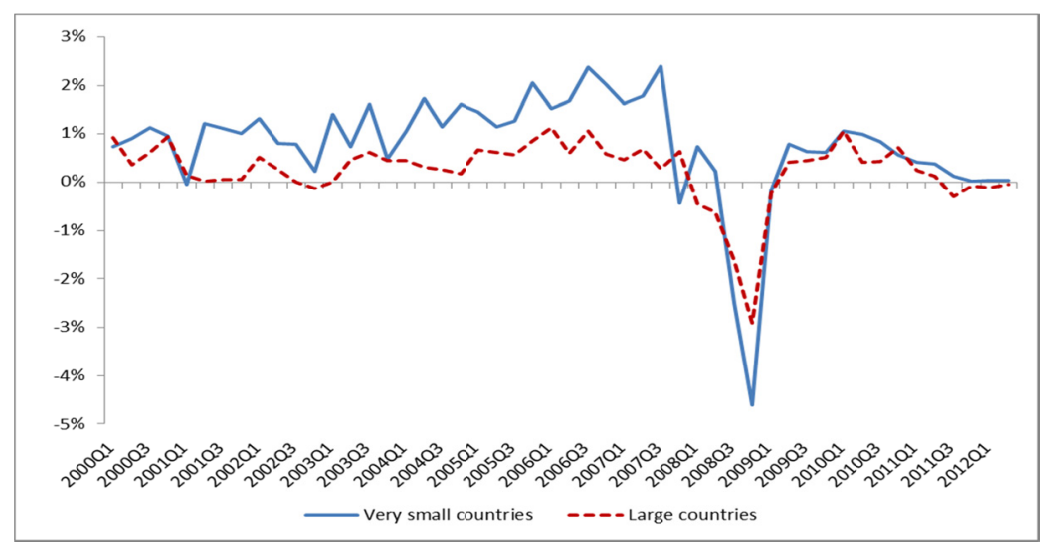

Figure 1. Quarter-on-Quarter real GDP growth (seasonally adjusted)

Source: Eurostat.

Table 1 illustrates even more starkly this difference in volatility. The coefficient of variation of GDP data of the smallest economies is more than three times that of the largest ones. Smaller countries face issues even in data compilation, with inventory changes and statistical discrepancies being, on average, greater than those of bigger economies. Both private and government consumption, as suggested by the literature, are much more volatile in the smallest EA countries. The range of quarter-on-quarter changes in these national accounts components is very high in very small economies. Successive quarter-on-quarter changes tend to vary very substantially in these countries, whereas in the larger economies developments are much smoother. Exports and investment are quite volatile in the largest EA countries, but still not to the extent observed in very small economies. To exacerbate things, both exports and investment constitute a much higher ratio to GDP for the very small EA 
economies. The completion of large orders or gains of significant orders by individual enterprises can affect export turnover in the latter cases. Similarly, in a very small economy, capital projects tend to be relatively larger and more one-off than in a bigger economy. Figure 2 shows how while investment in the largest EA economies follows relatively smooth cyclical behaviour, for the smallest countries it is replete of temporary surges and drops.

Table 1. Indicators of volatility (2000-2012)-the impact of country size

\begin{tabular}{lccc}
\hline & Very small countries* & Small countries* & Large countries* \\
\hline Coefficient of variation (\%) & 13.2 & 6.5 & 4.3 \\
GDP & 11.5 & 6.6 & 3.5 \\
Private consumption & 11.1 & 6.5 & 6.7 \\
Gov. consumption & 22.2 & 12.3 & 14.0 \\
Exports & 15.4 & 8.7 & 9.5 \\
Investment & 7.0 & & 4.0 \\
\hline Range of quarter-on-quarter changes (percentage points) & 4.1 & 1.4 \\
GDP & 4.2 & 3.0 & 1.4 \\
Private consumption & 7.7 & 4.6 & 13.4 \\
Gov. consumption & 15.0 & 11.9 & 9.5 \\
Exports & 15.4 & 8.7 & 0.20 \\
Investment & & & 0.04 \\
Odds of successive quarter-on-quarter changes varying by more than 0.5 p.p. & 0.33 & 0.00 \\
GDP & 0.45 & 0.10 & 0.71 \\
Private consumption & 0.33 & 0.20 & 0.45 \\
Gov. consumption & 0.78 & 0.80 & 0.1 \\
Exports & 0.82 & 0.57 & \\
Investment & 0.84 & 0.4 & \\
\hline Mean value of Inventory & 0.3 & & \\
changes/Statistical discrepancy (\% & & & \\
of GDP) & & & \\
\hline
\end{tabular}

* Very small countries have a GDP less than $1 \%$ of total EA GDP, that of small countries is between $1 \%$ and $5 \%$, while the large economies are the remaining EA countries.

Source: Own analysis using Eurostat GDP seasonally-adjusted quarterly data.

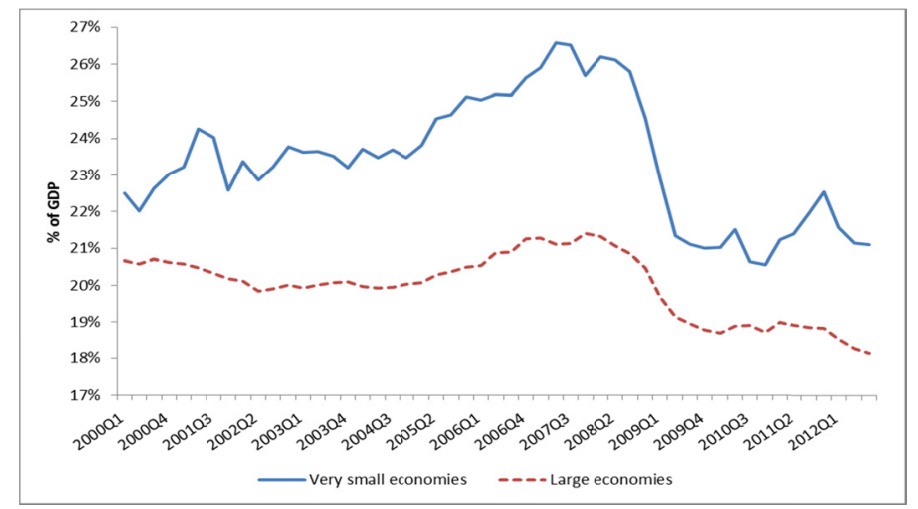

Figure 2. Investment as a ratio to GDP (seasonally adjusted)

Source: Eurostat.

\section{Modifying the HP Filter}

The estimation of potential output has tended to be done in two ways. One school, harking back to the classical tradition, views the business cycle as fluctuations around a long-term trend, with the economy having some form of mean-reverting process that leads it back to equilibrium. By contrast, the other line of thinking, which draws 
from Keynesian macroeconomics, allows for the possibility of permanent or long-term divergences and sees the output gap as the result of significant movements in aggregate demand in relation to a slowly moving level of aggregate supply. The emergence of an output gap is attributed to rigidities that delay the immediate adjustment of prices and wages. Conversely, the first line of thinking sees potential output as being 'driven by exogenous productivity shocks to aggregate supply that determine both the long-term economic growth and, to a large extent, short-term fluctuations in output over the cycle' (Note 10).

Broadly speaking, potential output in neoclassical macroeconomic thought is synonymous with the trend growth rate of actual output. The output series can be decomposed into a permanent component and a cyclical one that exhibits stationary behaviour in that it reverts always to the permanent level. What complicates matters is that the permanent or equilibrium level of output, however, is not stable and instead exhibits an upward trend in most economies, reflecting mainly productivity shocks. Therefore methods that attempt to extricate the cyclical element must be able to identify movements in the time series that are due to the cycle and those that reflect changes in potential output. The most popular filtering method is the HP filter (Note 11) which takes the form:

$$
\operatorname{Min}\left(\sum_{t=1}^{T}\left(y_{t}-\tau_{t}\right)^{2}+\lambda \sum_{t=2}^{T-1}\left[\left(\tau_{t+1}-\tau_{t}\right)-\left(\tau_{t}-\tau_{t-1}\right)\right]^{2}\right)
$$

This first term minimises the distance between the actual and the potential $\left(\tau_{t}\right)$ value, while the second minimises the change in the trend value. Given that these two objectives contradict each other, the weight $\lambda$ is used to control for the smoothness of the trend. It is typically set at 1600 for quarterly data. Its widespread use derives mainly from its simplicity, though it has other useful properties, for example it produces an output gap that is stationary even though the original series is integrated.

Despite its popularity, its use has been controversial. It is mechanistic and results depend crucially on the choice of $\lambda$. If $\lambda$ is set to zero, the trend is the same as the actual series, while if it is set at infinity it reduces to the linear form. The arbitrary choice of the smoothing parameter influences the size of potential output estimates and some studies have argued that the commonly used $\lambda$ s are only applicable for the normal business cycle of the US (Note 12). Long run deviations from equilibrium are ruled out, and the filter assumes the cycle lasts between 2 and 32 quarters. The method also suffers from an end-of-sample problem (Note 13). Baxter \& King (1999) find it takes data for three additional years to make sure the actual output gap makes sense (Note 14). Cotis et al (2005) argue that 'the sample end point weaknesses characterising HP filtering are beyond practical remedy' given that official forecasters tend to adopt a "back to average growth" forecasting approach. Another criticised feature of the HP filter is that it assumes the cycle is symmetric. In addition, Scacciavillani (1999) notes that if there are structural breaks, the use of the HP filter 'could be inappropriate since the filtering procedure may remove from the data shifts that in fact represent a change in the trend level or growth rate of potential output'. Guay \& St-Amant (2005) also note that it is based on assumptions that are unlikely to be satisfied in practice; namely that transitory and trend components are not correlated with each other, that the process is integrated of order 2 , and that the transitory component is white noise.

Structural methods tend to be preferred by policymaking institutions as their results are relatively easier to 'to frame economic policy discussions or explain policy decisions to the public' (Note 15). While potential output is not something which is expected to drop, there is increasing evidence that its growth is affected by severe financial crises or deep recessions (Note 16). Structural methods have the advantage that they can allow for longer deviations from potential. The main method used is the production function approach (Note 17), involving the modelling of aggregate supply via an economy-wide production function. Despite its attractiveness, this presents significant practical drawbacks for very small economies, as data requirements are substantial. Arriving at a measure of capital stock is difficult (Note 18). Furthermore systematic deviations of output from the level given by factor inputs, ascribed to total factor productivity (TFP) growth, tend to require the use of de-trending techniques and result in very large changes for small countries as factors of production may be measured incorrectly (Note 19). Other structural alternatives to production functions, such as structural VARs (Note 20) and micro-founded dynamic stochastic general equilibrium models (Note 21) are equally hard to implement for very small economies. Semi-structural methods (Note 22), such as the multivariate Beveridge-Nelson decomposition, which try to use statistical approaches in a structural context by using information from several series to estimate the output gap, are less challenging. Yet they still are problematic. For instance, the unobserved components method (Note 23) tries to extract information on the output gap using the co-movement of observed series, such as inflation, but these too could also be subject to shocks that have little to do with changes in potential output (Note 24). Modifying the simple HP filter to try to account for the 
particular needs of very small open economies, while also allowing for more flexibility in determining the length of deviations from potential, may present an interesting alternative.

\subsection{A suggested Alternative Use of The Standard HP Filter}

Due to noise in the data, applying the HP filter on the GDP series of a very small open economy gives the impression that the output gap is very volatile (Note 25). For instance when applied to the smallest country, Malta (Note 26), the filter yields an output gap series that ranges between $-3.4 \%$ and $+3.8 \%$ of potential GDP. This is not that different from that of the EA (i.e. $-2.6 \%$ to $+3.3 \%$ ). However, while the Maltese series is stationary, as can be seen from Figure 3 it is erratic and does not display clear cyclical behaviour. For instance, looking at 2000, it moves from a gap of $0.9 \%$ in the first quarter to a surplus of $2.3 \%$ in the second, a gap of $0.2 \%$ in the third and a surplus of $1.7 \%$ in the last quarter. The Maltese series changes sign 18 times while the EA's does so 6 times (Note 27). The relevance of such a measure of 'equilibrium' is clearly limited and it cannot serve as a good guide for decisions on economic policy.

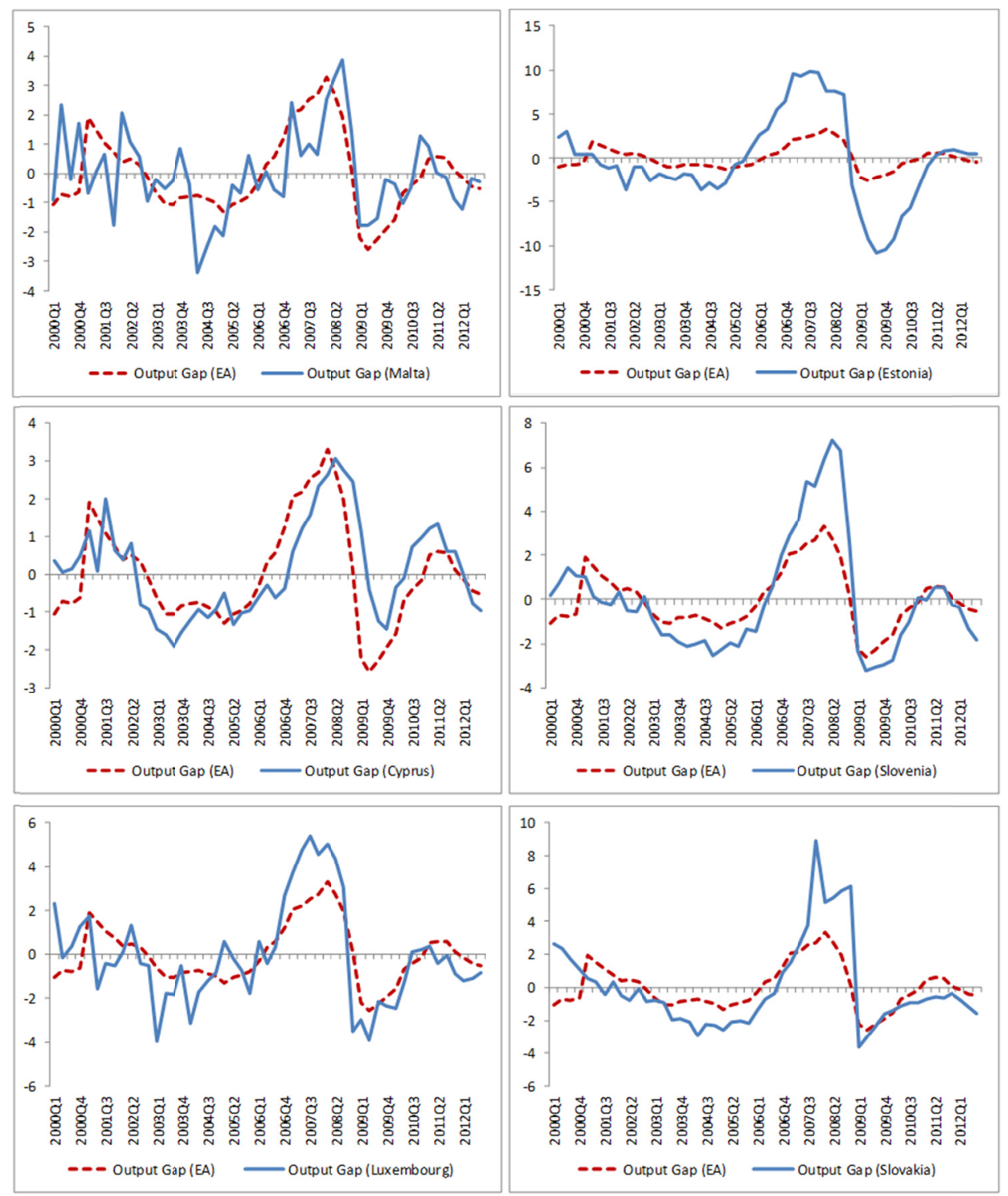

Figure 3. Output gap (HP filter on seasonally-adjusted quarterly GDP data)

Source: Own calculations using Eurostat data.

The variability of the HP-filtered output gap measure for very small open economies can however be reduced. The first step is to divide their GDP time series into an upper and a lower bound data sequence. The upper bound 
takes all those GDP readings which are underpinned by a quarter-on-quarter increase, while the lower bound takes the readings resulting from a decline. The successive actual values of these series are interpolated to create a complete time series (Note 28) that is considerably smoother than the actual GDP series, which is characterised by very large spikes and subsequent drops. Following this, an HP filter is applied separately on the upper and lower data sequence. Then for some weight, $\theta$ (with a value between 0 and 1), one would define the potential output series as:

$$
\theta Y_{L}+(1-\theta) Y_{H}
$$

where $Y_{L}$ stands for the trend of the lower bound of the series while $Y_{H}$ is the trend fitted to the upper bound. One would set the value of $\theta$ on the basis of an assessment as to where the equilibrium lies. It would be closer to 1 the more one believes that equilibrium lies close to the trend set by the lower bound of the time series, and vice versa. As GDP in small open economies tends to be boosted by one-off events such as large capital projects and bulky export orders, choosing a $\theta$ of 1 would appear preferable. Conversely given that potential output is generally taken to mean 'maximum' output, one could argue that the bias for $\theta$ should be closer to 0 . The setting of $\theta$ introduces an element of judgement, which inevitably implies that the method is not easy to standardise across countries.

Adopting a constant $\theta$ does not necessarily affect the variability of the output gap estimates. It just allows one to have a lower potential output series. Varying $\theta$ over time can, however, help reduce the variability of the output gap. The algorithm used to determine this variation was based on observing the changes in the standard HP filter derived output gap for the very small economy and comparing them with those of a larger (and more stable) economy - in this case, the EA as a whole. Whenever the change in the standard HP filter output gap for the very small economy was substantially larger than that in the EA, the $\theta$ was changed to $1-\theta$, so that the upper bound series is given the weight usually given to the lower bound. In this way, potential output is allowed to react when there is a spike in growth, but not be dragged downwards excessively by abrupt downturns. The selection of the value of $\theta$ for each country was based on that value that gave the lowest standard deviation for the resulting output gap series.

As can be seen from Figure 4, the output gap series resulting from the modified approach for all very small EA countries is smoother than that derived from the standard HP filter. Returning to the earlier example of the output gap estimates for 2000 for Malta, these are now all positive values, rather than have a different sign each quarter. Table 2 summarises some volatility indicators. The number of times the output gap changes sign is much lower, and more in line with the changes for the EA as a whole. While the smallest EA economies still have a relatively higher-than-average volatile series, the cycles are slightly better-defined. The time span between changes in sign of the quarterly output gap converges, for most of the countries, a bit more to the EA average. Even more interestingly, the modified approach lowers substantially the range of the second difference in the quarterly output gap series of these very small economies.

Table 2. Indicators of output gap volatility-the impact of modified approach

\begin{tabular}{|c|c|c|c|c|}
\hline & $\begin{array}{c}\text { Chosen value } \\
\text { of } \theta\end{array}$ & $\begin{array}{c}\text { Changes in sign of } \\
\text { successive output gap } \\
\text { estimate }\end{array}$ & $\begin{array}{l}\text { Average no. of quarters } \\
\text { between change in sign }\end{array}$ & $\begin{array}{c}\text { Range of second difference in } \\
\text { output gap (p.p.) }\end{array}$ \\
\hline Malta & 0.999 & $13(18)$ & $3.6(2.7)$ & $6.7(12.0)$ \\
\hline Estonia & 0.965 & $4(4)$ & $10.2(10.2)$ & $15.7(16.7)$ \\
\hline Cyprus & 0.999 & $5(5)$ & $8.5(8.5)$ & $5.5(6.3)$ \\
\hline Slovenia & 0.458 & $5(9)$ & $8.5(5.1)$ & $7.6(7.7)$ \\
\hline Luxembourg & 0.790 & $9(13)$ & $5.1(3.6)$ & $11.8(12.3)$ \\
\hline Slovakia & 0.489 & $5(5)$ & $8.5(8.5)$ & $7.7(20.3)$ \\
\hline EA & NA & (6) & $(7.3)$ & (5.4) \\
\hline
\end{tabular}

Note: Figures in ( )s denote values derived using the standard HP filter. 

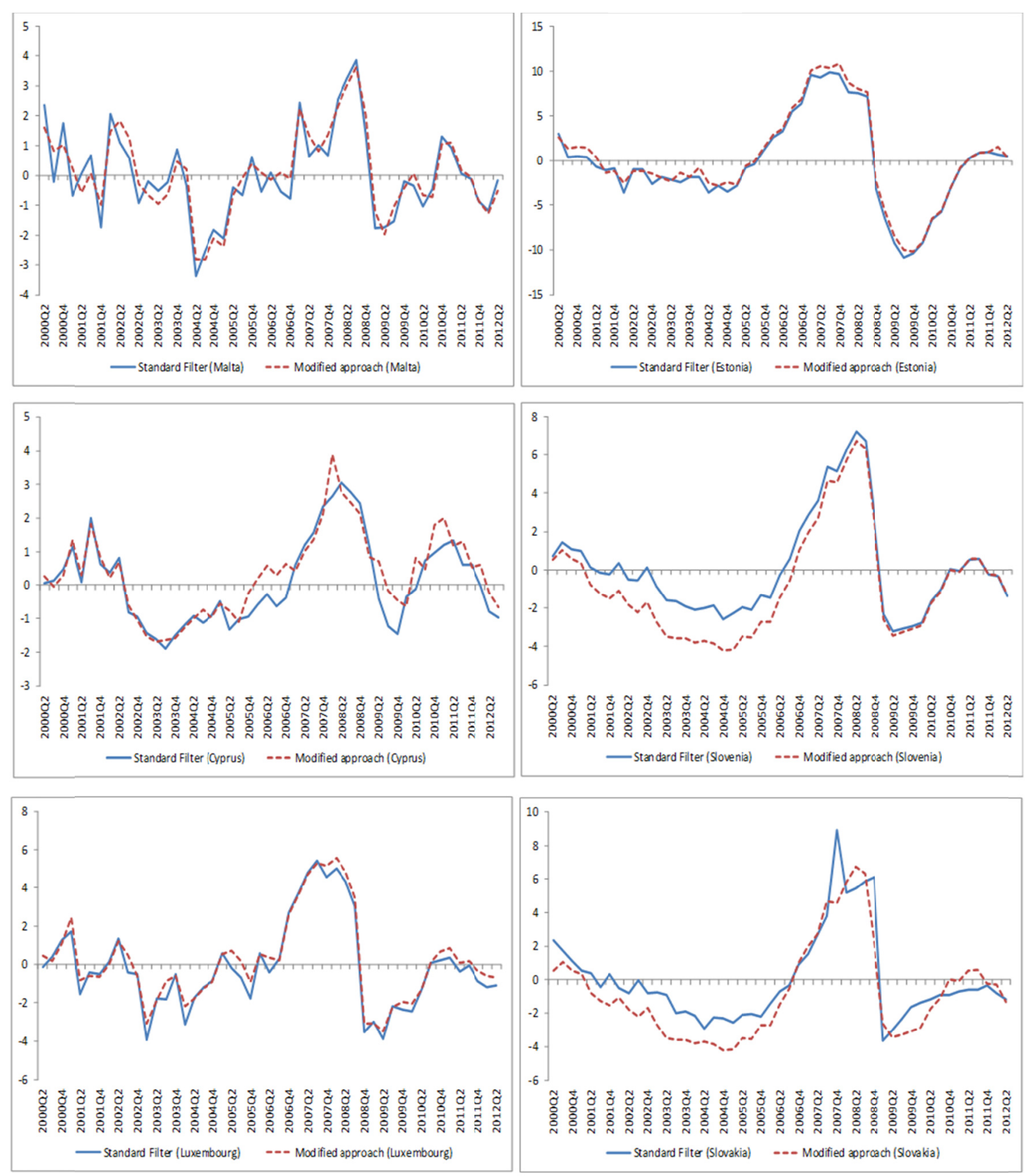

Figure 4. Output gap resulting from using standard HP filter and the modified approach

Source: Own calculations using Eurostat data.

The values of $\theta$ in this exercise were chosen to smoothen as much as possible the changes in quarterly output gap by linking it to changes observed for the more stable EA average. However another potential use of this approach is to allow for long-term deviations from equilibrium. This is particularly useful if the series one has to work with is very short - a common occurrence when working with data for small open economies. In this case, one could set the factor $\theta$ on the basis of considerations from other data (e.g. indications from changes in inflation rates, sentiment indicators or capacity utilisation rates) or by looking at developments in related economies for which the data series is longer and less affected by one-off events. If one sets $\theta$ close to 1 , the series for the gap has a positive mean value and the reverse for $\theta$ close to 0 . Of course, the extent of the deviation can be controlled by applying the factor differently in different time periods. For instance, in an initial period where the researcher believes there was under-employment of resources, $\theta$ would be set closer to 0 and then this would be changed gradually to become closer to 1 . The other thing to consider is that the extent to which $\theta$ would need to be 
modified depends crucially on the nature of the upper and lower bound series. When there is a noticeable gap, the setting of $\theta$ would require more thought.

\subsection{A Suggested Modification to the Standard HP Filter}

Due to its shortcomings, there have been several attempts to modify the HP filter. Chagny \& Dopke (2001) describe one such attempt - the multivariate HP filter (Note 29). The latter attempts to give the filter an economic basis by means of three structural equations, namely an augmented Phillips curve with inflation depending on expected inflation and the current and lagged output gap, an Okun's law relation with current unemployment depending on an exogenously determined NAIRU and the current and lagged output gap and capacity utilisation compared vis-à-vis its optimal level. A loss function is then set up that minimises the standard HP filter and the residuals of these three equations. The problem the authors note in this approach is that it is hard to judge the weight to set to the structural equations in the loss function.

Ross \& Ubide (2001) review another modification known as HP-ARIMA. The latter aims to minimise the end-of-sample problem by forecasting and backcasting the series with an ARIMA model. Since the choice of the smoothing parameter, $\lambda$, amounts to identifying the allocation of variations in output to trend and to cyclical components, they suggest calculating $\lambda$ in a cross-country setting so as to equalise the volatility of the trend across countries, using one country as the benchmark (Note 30). They propose two methods; allowing for a larger variability of the growth rate in countries with a more volatile component, or else assuming similar economic structures between the benchmark and the comparator country.

Dennis \& Razzak (1995) make another important contribution, basing their modification to the standard HP filter on the fact that $\lambda$ can be interpreted as a function of the ratio of the variances of aggregate demand and supply. They note that setting a constant $\lambda$ implicitly assumes that the relative variances of demand and supply disturbances of output are time-invariant. Applying their thinking to the case of New Zealand, a small open economy, they suggest that keeping $\lambda$ constant does not make sense. New Zealand's GDP has undergone a number of significant structural shocks and they argue in favour of allowing $\lambda$ to vary with time to reflect changes in the variation of aggregate demand and supply (Note 31). The idea of having a time-variant $\lambda$ is attractive as the effect of structural shocks and one-off factors could be reduced and, thus, the potential output series would give a fairer picture of the equilibrium of the economy. However, there is an alternative way to arrive at a similar result via a more fundamental modification of the standard HP filter, intended to give researchers more leeway to reduce the mechanistic nature of the filter and adjust it for underlying characteristics of a particular series.

Consider the following modification of the standard HP filter:

$$
\operatorname{Min}\left(\sum_{t=1}^{T} w_{t}\left(y_{t}-\tau_{t}\right)^{2}+\lambda \sum_{t=2}^{T-1}\left[\left(\tau_{t+1}-\tau_{t}\right)-\left(\tau_{t}-\tau_{t-1}\right)\right]^{2}\right)
$$

The second part of the equation (including $\lambda$ ), which smoothens the growth in potential output, is the same. Instead the first part of the equation now includes an additional term $w_{t}$. This is a generalisation of the standard filter, which is the case when $\mathrm{w}_{t}$ is 1 . The weight $\mathrm{w}_{t}$ is the means by which the filter is modified to suit better a series' characteristics.

The choice of this weight would reflect two considerations, namely:

a) $\mathrm{w}_{t}$ is smaller the more $\mathrm{y}_{t}$ is below the previous high $y$ value, with maximum $\mathrm{w}_{\mathrm{t}}=1$ when $\mathrm{y}_{\mathrm{t}}$ is higher or equal to the previous high. More formally, if the previous high $y$ at time $t$ is $\mathrm{h}_{\mathrm{t}}$, then:

$$
w_{t}=\frac{1}{1+\mu\left\{\max \left(h_{t}-y_{t}, 0\right)\right\}}
$$

Through this modification, a researcher is able to control the extent to which potential output falls in level by means of the value of the factor $\mu$. A higher $\mu$ means less weight is given to quarters when GDP is much lower than it used to be. The logic behind this is that drops in the level of potential output are rare and occur only when resources or knowledge are destroyed. Statistical filters should therefore have a bias against declines in equilibrium output. In the case of very small open economies, this bias is particularly important as due to their size, these countries tend to have very volatile investment, government consumption and export figures, due to projects and orders being large and one-off in nature.

b) $w_{t}$ is lower the greater the time difference between $y_{t}$ and $h_{t}$. Letting $p_{t}$ denote this difference: 


$$
w_{t}=\frac{1}{1+\varphi\left\{\max \left(p_{t}, 0\right)\right\}}
$$

This modification introduces the possibility that there may be long-term deviations from equilibrium. This is done by means of the factor $\varphi$. For any given $\varphi$, for a decline in output to be allowed to affect the level of potential output, the decline must persist for some time. In the standard HP filter, declines in output automatically result in lower potential GDP, thus eliminating the possibility of long disequilibria. With this modification the researcher has the discretion to allow for longer periods when output is below potential.

Uniting these two concepts, the weight $\mathrm{w}_{\mathrm{t}}$ in the first part of the HP filter is:

$$
w_{t}=\frac{1}{1+\mu\left\{\max \left(h_{t}-y_{t}, 0\right)\right\}} \times \frac{1}{1+\varphi\left\{\max \left(p_{t}, 0\right)\right\}}
$$

This new weight has two parts: the first affecting the impact of temporary shocks on a series and the second allowing for long-term deviations from equilibrium. As a result, the solution of the generalised HP filter differs slightly from that of the standard filter, as one needs to consider the influence of $\mathrm{w}_{\mathrm{t}}$. Whereas the solution of the minimisation problem in the standard filter (Note 32) is:

$$
\tau=\left(I_{T}+\lambda K^{\prime} K\right)^{-1} X
$$

Where $\tau$ is a vector with the values of the filtered series, $I_{T}$ is the identity matrix with dimension $T, X$ is a vector with the readings of the series being filtered, $\lambda$ is the smoothing parameter, and

$$
K=\left(\begin{array}{ccccccccc}
1 & -2 & 1 & 0 & 0 & \cdots & 0 & 0 & 0 \\
0 & 1 & -2 & 1 & 0 & \cdots & 0 & 0 & 0 \\
0 & 0 & 1 & -2 & 0 & \cdots & 0 & 0 & 0 \\
\vdots & \vdots & \vdots & \vdots & \vdots & \cdots & \vdots & \vdots & \vdots \\
0 & 0 & 0 & 0 & 0 & \cdots & 1 & -2 & 1
\end{array}\right)
$$

In the generalised filter, $\mathrm{X}$ is a vector with the values of the series being filtered multiplied by their respective wt. The choice of $\mu$ and $\varphi$ depend on the characteristics of the series. The closer they are to 0 , the more the underlying series is allowed to determine potential output (Note 33). On the statistical side, the issues to keep in mind are the variability of the series and the possibility that downward movements in a series may be more serious than upturns (i.e. leverage issues). On the economic side, one needs to consider that inflation, unemployment and other such variables of interest to policymakers tend to respond more to upward movements in the GDP series than to downward movements. Not only are prices notoriously sticky downwards, but also the presence of labour hoarding in small economies typically means that unemployment takes time to rise after a downturn. These factors should be taken into consideration when setting $\mu$ and $\varphi$. The researcher would need to look at micro-studies or other evidence on several factors, such as the level of education of the workforce, the amount and quality of the capital stock and other measures of potential resources, past evidence of hysteresis effects, when trying to determine the value of $\mathrm{w}_{\mathrm{t}}$. The factors $\mu$ and $\varphi$ can also be interpreted as indicating the rate of adaptability of factors of production to economic shocks and the rate of recovery of an economy from downturns. Studies of past recessions or cross-country evidence on cyclical fluctuations would be useful in this regard.

Another thing to consider is whether to allow $\mu$ and $\varphi$ to vary over time. This would depend on whether there is evidence that there are noticeable changes in the adaptability of economic resources. For instance, in an economy where the production structure shifted substantially over time and new activity requires a much higher skilled, and thus less available, workforce, one might want to change $\mu$ and $\varphi$. Another thing to consider is judgement regarding noise in the data. It might be that a researcher has evidence that data quality in a particular period is worse than in others, and might want to address this by using time-varying factors. Similarly a researcher might want to use information from a more stable series to improve the reliability of the estimates from the generalised filter. For the purposes of this paper, we limited ourselves to test a range of values of $\mu$ and $\varphi$ between 0.001 to 0.999 and selected those which resulted in the lowest standard deviation, while imposing a 
rule that whenever the change in the output gap from the standard HP filter for each small country was larger than that in the EA average, the sign for the factors was changed, to try to address potential noise in the data.
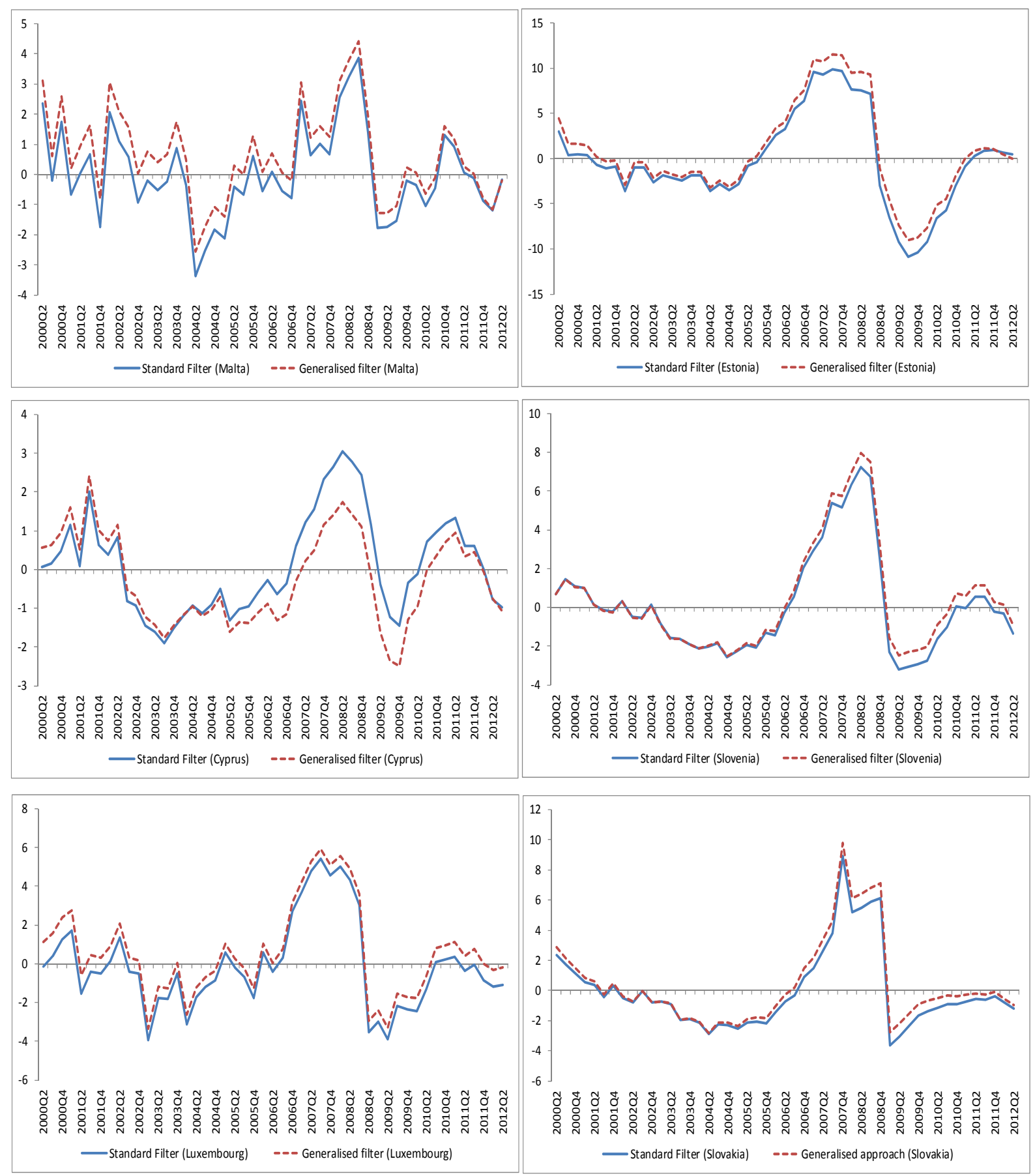

Figure 5. Output gap resulting from using standard HP filter and the generalised filter

Source: Own calculations using Eurostat data.

Figure 5 shows the estimates of the output gap resulting from the application of this generalised HP filter. Compared to the series derived using the modified approach described in section 3.1, the results are less smooth, particularly for the start of the period. However, similar to the modified approach, the generalised filter results in fewer changes in sign of the output gap, particularly within the same year (see Table 3). Further improvements of 
the algorithm used to set the parameters determining $\mu$ and $\varphi$ could result in a smoother series, but the scope of this exercise was just to introduce this approach (Note 34). Its benefits lie more in the fact it allows researchers to use evidence on factor adaptability and related considerations to reduce the mechanistic nature of the standard HP filter. To determine the right values of $\mu$ and $\varphi$ for each country would require in-depth country studies.

Table 3. Indicators of output gap volatility-the impact of the generalised filter

\begin{tabular}{lcccc}
\hline & $\begin{array}{c}\text { Chosen value of } \mu \\
\text { and } \varphi\end{array}$ & $\begin{array}{c}\text { Changes in sign of } \\
\text { successive output gap } \\
\text { estimate }\end{array}$ & $\begin{array}{c}\text { Average no. of quarters } \\
\text { between change in sign }\end{array}$ & $\begin{array}{c}\text { Range of second } \\
\text { difference in output gap } \\
\text { (p.p.) }\end{array}$ \\
\hline Malta & 0.015 & $12(18)$ & $3.9(2.7)$ & $11.4(12.0)$ \\
Estonia & 0.033 & $4(4)$ & $10.2(10.2)$ & $16.7(16.7)$ \\
Cyprus & 0.01 & $5(5)$ & $8.5(8.5)$ & $6.3(6.3)$ \\
Slovenia & 0.015 & $9(9)$ & $5.1(5.1)$ & $7.7(7.7)$ \\
Luxembourg & 0.011 & $9(13)$ & $5.1(3.6)$ & $12.3(12.3)$ \\
Slovakia & 0.015 & $5(5)$ & $8.5(8.5)$ & $20.3(20.3)$ \\
EA & NA & $(6)$ & $(7.3)$ & $(5.4)$ \\
\hline
\end{tabular}

Note: Figures in ( )s denote values derived using the standard HP filter.

\section{Discussion}

Having a reliable estimate of potential output is crucial for policymakers, both on a national and a supranational setting. This interest has fuelled significant research and a plethora of methods have been developed over the years. However the implementation of these approaches can be problematic when looking at very small open economies. Lack of data, and erratic developments in investment and labour demand, complicate the construction of a production function based on quarterly data. Quarterly GDP series, even when seasonally adjusted, do not fit well the statistical properties underpinning most standard filtering methods. Series for very small countries tend to be short, have large fluctuations and recurrent structural breaks. This paper has shown that when applied to the smallest EA countries, the HP filter results in very pronounced and recurrent changes in the output gap that are inconsistent with the theoretical idea of equilibrium. The filter is affected significantly by shocks to data, which in turn reflect the small size of these economies rather than actual changes in potential output.

On this basis, two suggestions were put forward. The first involves an innovative use of the standard filter, whereby the upper and lower bounds of a series are defined and the equilibrium level is determined as a weighted average of the HP filter applied separately on these bounds. This was shown to result in a smoother output gap series with the possibility of long-term deviations from equilibrium. The second suggestion involves a rethinking of the standard HP filter to integrate structural features. The modified or generalised HP filter allows researchers to set limits on the impact exerted by structural or temporary shocks and to allow for the possibility of having lengthy periods of disequilibria. These suggestions can be criticised as granting too much discretion to researchers and thus doing away with one of the main benefits of the HP filter, namely the lack of judgement needed to apply it. However, the special characteristics shown by the output series of very small open economies make this benefit appear to be more of a drawback. Rather than ignore the properties of the series being studied, the two suggestions allow researchers to apply their judgement and knowledge on a particular economy to arrive at a measure of equilibrium that is based on sounder reasoning, while not involving the complexity of constructing a model. Though this would probably lead to various estimates of the output gap being made for the same economy, a healthy debate between economists on the adequate parameters to be set is much to be preferred to a blind adherence to a standardised filtering method. Given the importance of gauging the level of potential output properly, it is better to have a number of partially correct opinions rather than one incorrect result.

\section{Acknowledgements}

This paper builds on research the author conducted under the supervision of Jerzy Szroeter at University College London. The author would like to thank him for his help and suggestions. The comments on an earlier draft of the paper by Brian Micallef, a colleague at the Central Bank of Malta, are also acknowledged. The author would also like to thank Alfred DeMarco, Deputy Governor of the Central Bank of Malta, for his help. 


\section{References}

Alesina, A., \& Spolaore, E. (2003). The size of nations. Cambridge, Massachusetts: MIT Press.

Alesina, A., Spolaore, E., \& Wacziarg, R. (2004). Trade, growth and the size of countries. In Aghion, P., \& Durlauf, S. (Eds.), Handbook of Economic Growth (Vol. 1, Part 2, Chapter 23, pp. 1499-1542). Amsterdam: North Holland.

Areosa, M. (2008). Combining Hodrick-Prescott filtering with a production function approach to estimate output gap. Banco Central do Brasil: working paper 172. Retrieved from http://www.bcb.gov.br/pec/wps/ingl/wps172.pdf

Artis, M., Marcellino, M., \& Proietti, T. (2003). Dating the Euro Area business cycle. IGIER, Universita' Bocconi: working paper 237. Retrieved from ftp://ftp.igier.uni-bocconi.it/wp/2003/237.pdf

Baxter, M., \& King, R. G. (1999). Measuring business cycles-Approximate band-pass filters for economic time series. The Review of Economics and Statistics, 81(4), 575-593. http://dx.doi.org/10.1162/003465399558454

Blanchard, O. J., \& Quah, D. (1988). The dynamic effect of aggregate demand and supply disturbances. American Economic Review, 79(4), 655-673. Retrieved from http://www.jstor.org/stable/1827924

Canova, F. (1998). De-trending and business cycle facts. Journal of Monetary Economics, 41(3), 475-512. http://dx.doi.org/10.1016/S0304-3932(98)00006-3

Chagny, O., \& Dopke, J. (2001). Measures of output gap in the Euro-zone: An empirical assessment of selected methods. Kiel Institute of World Economics: working paper 1053. Retrieved from http://mercury.ethz.ch/serviceengine/Files/ISN/124047/ipublicationdocument_singledocument/781743a3-72 78-42d7-9458-731179884e94/en/kap1053.pdf

Claus, I., Conway, P., \& Scott, A. (2000). The output gap: Measurement, comparisons and assessment. Reserve Bank of New Zealand: research paper 44. Retrieved from www.rbnz.govt.nz/research_and_publications/research.../rp44.pdf

Commonwealth Advisory Group. (1997). A future for small states: Overcoming vulnerability. London: The Commonwealth.

Cotis, J. P., Elmeskov, J., \& Mourougane, A. (2005). Estimates of potential output: Benefits and pitfalls from a policy perspective. In Reichlin, L. (Ed.), The Euro Area business cycle: Stylized facts and measurement issues. London: CEPR.

D’Auria, F., Denis, C., Havik, K., McMorrow, K., Planas, C., Raciborski, R., Roger, W., \& Rossi, A. (2010). The production function methodology for calculating potential growth rates and output gaps. European Economy: economic $\quad 420.4$ Retrieved from http://ec.europa.eu/economy_finance/publications/economic_paper/2010/pdf/ecp420_en.pdf

De Masi, P. R. (1997). IMF estimates of potential output: Theory and practice. International Monetary Fund: working paper WP/97/177. Retrieved from http://www.imf.org/external/pubs/ft/wp/wp97177.pdf

Denis, C., McMorrow, K., \& Roger, W. (2002). Production function approach to calculating potential growth and output gaps-estimates for the EU Member States and the US. European Economy: economic paper 176. Retrieved from http://ec.europa.eu/economy_finance/publications/publication1706_en.pdf

Dennis, R., \& Razzak, W. A. (1995). The output gap using the Hodrick-Prescott filter with a non-constant smoothing parameter: An application to New Zealand. Reserve Bank of New Zealand: discussion paper 95/8. Retrieved from http://www.razzakw.net/paper5.pdf

Economic Policy Committee. (2001). Report on potential output and the output gap. Report to the Directorate Generale Economic and Financial Affairs: European Commission. Retrieved from http://europa.eu/epc/pdf/finaloutput_en.pdf

European Central Bank. (2000). Potential output growth and output gaps: Concepts, uses and estimates. European Central Bank: Monthly Bulletin, (10), 37-48.

European Central Bank. (2011). Trends in potential output. European Central Bank: Monthly Bulletin, (1), $73-$ 85.

European Commission. (2009). Impact of the current economic and financial crisis on potential output. European Economy: occasional paper 49. Retrieved from 
http://ec.europa.eu/economy_finance/publications/publication15479_en.pdf

European Commission. (2012). Specifications on the implementation of the stability and growth pact and guidelines on the format and content of stability and convergence programmes. Retrieved from http://ec.europa.eu/economy_finance/economic_governance/sgp/pdf/coc/code_of_conduct_en.pdf

Giorno, C., Richardson, P., Roseveare, D., \& Van den Noord, P. (1995). Estimating potential output, output gaps and structural budget balances. Organisation for Economic Co-operation and Development: working paper 152. Retrieved from http://www.oecd.org/eco/outlook/33928808.pdf

Guay, A., \& St-Amant, P. (2005). Do the Hodrick-Prescott and Baxter-King filters provide a good approximation of business cycles? ENSAE: Annales d'Economie et de Statistique, No.77. Retrieved from http://www.er.uqam.ca/nobel/r27460/files/Hodrick_Prescott.pdf

Haltmaier, J. (2012). Do recessions affect potential output? Board of Governors of the Federal Reserve System: International Finance Discussion Paper No 1066. Retrieved from http://www.federalreserve.gov/pubs/ifdp/2012/1066/ifdp1066.pdf

Hodrick, R. J., \& Prescott, E. C. (1997). Post-war US business cycles: An empirical investigation. Journal of Money, Credit and Banking, 29(1), 1-16. http://dx.doi.org/10.2307/2953682

Kuznets, S. (1960). Economic Growth of Small Nations. Economic consequences of the size of nations. New York: St. Martin's Press.

Ladiray, D., Mazzi, G. L., \& Sartori, F. (2003). Statistical methods for potential output estimation and cycle extraction. Retrieved from http://epp.eurostat.ec.europa.eu/cache/ITY.../KS-AN.../KS-AN-03-015-EN.PDF

Laurent, E. (2008). Economic consequences of the size of nations, 50 years on. Observatoire Francais des Conjonctures Economiques: working paper 2008-26. Retrieved from http://www.ofce.sciences-po.fr/pdf/dtravail/WP2008-26.pdf

Musso, A., \& Westermann, T. (2005). Assessing potential output growth in the euro area: A growth accounting perspective. European Central Bank: occasional paper 22. Retrieved from http://www.ecb.int/pub/pdf/scpops/ecbocp22.pdf

Okun, A. (1962). Potential GDP: Its measurement and significance. American Statistical Association, Proceedings of the Business and Economic Statistics Section: 98-103. Washington.

Rodrik, D. (1998). Why do more open economies have bigger governments? Journal of Political Economy, 106(5), 997-1032. http://dx.doi.org/10.1086/250038

Ross, K., \& Ubide, A. (2001). Mind the gap: What is the best measure of slack in the Euro Area? International Monetary Fund: working paper WP/01/203. Retrieved from http://www.imf.org/external/pubs/ft/wp/2001/wp01203.pdf

Scacciavillani, F., \& Swagel, P. (1999). Measures of potential output: An application to Israel. International Monetary Fund: working paper WP/99/96. Retrieved from www.imf.org/external/pubs/ft/wp/1999/wp9996.pdf

St-Amant, P., \& Van Norden, S. (1997). Measurement of the output gap: A discussion of recent research at the Bank of Canada. Bank of Canada: technical report No.79. Retrieved from http://www.bankofcanada.ca/wp-content/uploads/2010/01/tr79.pdf

Vetlov, I., Hledik, T., Jonsson, M., Kucsera, H., \& Pisani, M. (2011). Potential output in DSGE models. European Central Bank: working paper 1351. Retrieved from http://www.ecb.europa.eu/pub/pdf/scpwps/ecbwp1351.pdf

\section{Notes}

Note 1. In his seminal paper, Okun (1962) defined potential GDP as the answer to the question: "How much output can the economy produce under conditions of full employment?". For literature surveys of the topic see De Masi (1997), European Central Bank (2000) and Chagny \& Dopke (2001).

Note 2. Besides its use as a measure of inflationary pressures and/or the extent of under-utilisation of resources, the output gap serves other important purposes, which are more medium-term. It is used to adjust cyclically variables, such as the fiscal deficit, to reflect the levels that would prevail were the economy to operate at potential (see for instance Giorno et al (1995)). The European Union has gone as far as including this concept in the Stability and Growth Pact, and uses it to assess the progress made by countries towards achieving the goal of 
medium-term fiscal balance.

Note 3. For a review of the various statistical methods, see Ladiray et al (2003).

Note 4. For recent estimates of potential output for Euro area economies, see European Central Bank (2011).

Note 5. In fact, at the end of 2012 taken together these countries accounted for $1.9 \%$ of total EA GDP.

Note 6. See Commonwealth Advisory Group (1997).

Note 7. See for instance Laurent (2008) and Alesina et al (2004).

Note 8. World Bank Development Indicators show that in 2005, for instance, the gross saving rate for small states amounted to $27 \%$ as against $20 \%$ in the EU and the OECD.

Note 9. For example, between the last quarter of 2001 and the first quarter of 2002, the smallest economy, Malta, had quarter-on-quarter real GDP growth moving from $-2.1 \%$ to $+4.2 \%$. In the second quarter of 2007 real GDP fell by $1.2 \%$ after having risen by $3.9 \%$ in the previous quarter. By contrast, the largest change seen in the largest economy, Germany, was the sharp recovery from a drop of $4 \%$ in the first quarter of 2009 to positive $0.2 \%$ in the following quarter. For one third of the series, the change in quarter-on-quarter growth in Malta is larger than the second-largest quarter-on-quarter change in the German GDP data.

Note 10. Scacciavillani (1999).

Note 11. This method is described in Hodrick \& Prescott (1997).

Note 12. Chagny \& Dopke (2001).

Note 13. St-Amant $\&$ van Norden (1997) show that observations at the centre of the sample receive a 6 percent weight while the last observation accounts for 20 percent of the weight. Thus estimates of the gap for recent periods tend to change substantially as new (or revised) data are available.

Note 14. They also criticise the usual $\lambda$ 's set for annual data, 100 and 400, and suggest a weight of just 10.

Note 15. Economic Policy Committee (2001). The EU Commission, for instance, decided to stop using the HP filter as its main gauge of potential output and to instead develop a simple production function.

Note 16. Haltmaier (2012) finds, for instance, that 'the Great Recession might have resulted in declines in trend output growth averaging about 3 percent for the advanced economies, but appear to have had little effect on emerging market trend growth'. Similar results are found in European Commission (2009).

Note 17. See for example Denis et al (2002) and Musso \& Westermann (2005).

Note 18. D'Auria et al (2010) remark that no capital stock data was available for most small EU countries, and this series had to be constructed using common assumptions for all countries. Data on hours worked, another important component, tend to exhibit considerable noise and breaks compared to larger countries.

Note 19. European Commission estimates of TFP for Malta, for instance, imply that from a growth rate of 7.3\% in 2001, in 2002 there was a decline of $-7.8 \%$. By contrast the largest change for a bigger economy, like Germany or Italy, was of about 4 to 5 percentage points during the financial crisis. For further information see https://circabc.europa.eu/faces/jsp/extension/wai/navigation/container.jsp

Note 20. The first such example is suggested in Blanchard \& Quah (1989).

Note 21. Vetlov et al (2011).

Note 22. See Ross \& Ubide (2001), De Masi (1997) and Chagny \& Dopke (2001) for a survey of these methods.

Note 23. For a comprehensive explanation of this approach, see Claus et al (2000).

Note 24. To give an example, between January and June 2012, HICP inflation in Malta rose from 1.7\% to 4\%. This sharp acceleration, which was reversed in the following months, reflected a temporary spike in hotel prices - rather than any acceleration in underlying activity. Similarly inflation rose from $0.6 \%$ in March 2010 to $4 \%$ in December 2010, on the back of a surge in food prices, which moved from a negative $7.7 \%$ to a positive $8.3 \%$.

Note 25. Canova (1998) points out that filters assume 'that the irregular (high frequency) fluctuations play little role'.

Note 26. To reduce the end-of-sample problem, the GDP series for all countries were extended forwards for four years beyond the historical sample by means of a simple ARMA(1,1) forecast.

Note 27. The output gap series changes sign 13 times for Luxembourg and 9 times for Slovenia. The series for other countries may not change their sign as much, but they display the same pattern of random changes. 
Note 28. For simplicity's sake linear interpolation is used, but Lagrange interpolating polynomials could also be used.

Note 29. See Areosa (2008) for a somewhat similar modification of the HP filter.

Note 30 . In a way, this is how the factor $\theta$ was set in the previous section.

Note 31. Again the approach of setting a time-varying factor $\theta$ in the previous section follows this line of thinking.

Note 32. One takes the derivative of the minimisation problem with respect to $\tau$, re-arranges and converts to matrices.

Note 33. Of course they need to be less than 1, or else they would have too strong an impact. In the case of $\mu$ the value would need to be quite small, as the difference between current GDP and its previous peak could be quite high. In this paper we define this difference in terms of a percentage from the upper bound interpolated GDP series.

Note 34. For simplicity's sake, having a different value for $\mu$ and $\varphi$ was not looked into, for instance.

\section{Copyrights}

Copyright for this article is retained by the author(s), with first publication rights granted to the journal.

This is an open-access article distributed under the terms and conditions of the Creative Commons Attribution license (http://creativecommons.org/licenses/by/3.0/). 